\title{
A STUDY OF REGIONAL-LEVEL LOCATION FACTORS OF CAR MANUFACTURING COMPANIES IN THE EU*
}

\author{
Ottó CSÍKI - Réka HORVÁTH - Levente SZÁSZ \\ (Received: 29 May 2019; revision received: 26 October 2019; \\ accepted: 31 October 2019)
}

\begin{abstract}
The paper aims to explore how factors of regional competitiveness are associated with the location of car manufacturing companies in the EU. Although the European automotive market can be characterized by an intense dynamics in terms of location choices, literature offers little empirical guidance on how regional factors influence the location of car manufacturers in the EU. This paper aims to fill this gap by combining regional competitiveness data on $276 \mathrm{EU}$ regions with the actual location of all 269 production units of car manufacturing companies currently present in the EU. Logistic regression is used to discover significant relationships, while the comparative analysis of clusters of regions is meant to offer a more detailed understanding of the role of different location factors. Results of the analysis show that the most influential location factor is related to infrastructural development, but other competitiveness factors, such as regional innovation capabilities or labour market efficiency, might also play an important role.
\end{abstract}

Keywords: location, regional competitiveness, automotive industry, EU

JEL classification indices: R12, O18, M11, M16

* The research was funded by UEFISCDI Romania (Executive Agency for Higher Education, Research, Development and Innovation Funding), project No. PN-III-P1-1.1-TE-2016-0502.

Ottó Csíki, MSc student at the Faculty of Economics and Business Administration, Department of Economics and Business Administration in Hungarian Language, Babeş-Bolyai University, ClujNapoca, Romania. E-mail: csikiotto07@gmail.com

Réka Horváth, Assistant Professor at the Faculty of Economics and Business Administration in Hungarian Language, Babeş-Bolyai University, Cluj-Napoca, Romania.

E-mail: reka.horvath@econ.ubbcluj.ro

Levente Szász, corresponding author. Vice Dean and Full Professor at the Faculty of Economics and Business Administration, Department of Economics and Business Administration in Hungarian Language, Babeş-Bolyai University, Cluj-Napoca, Romania.

E-mail: levente.szasz@econ.ubbcluj.ro 


\section{INTRODUCTION}

Focusing on an industry characterized by dynamic changes in its value chain configurations, the purpose of this paper is to revisit and identify location factors in the European automotive industry, focusing specifically on the subsidiaries operated by all major car manufacturers present in the market of the European Union (EU). In this pursuit, we adopt a territory-based approach (Bilbao-Ubillos 2010) and investigate location factors on the regional level (Klier - McMillen 2015) to identify the most influential regional competitiveness factors that can be associated with the current location of automotive plants. While location decisions have been thoroughly analysed in the academic literature, the role of regional competitiveness in the location decisions of car manufacturing companies present in the EU has not yet been investigated. From a practical perspective, the main purpose of our research is to inform regional-level policy makers on the most important regional competitiveness factors that play a key role in attracting and retaining the production and R\&D units of car manufacturing companies.

Location decisions can have a significant impact on the long-term success of a company, as they usually require a large amount of investments and, once implemented, are difficult to reverse (Slack et al. 2016). Location decisions, especially those of multinational companies (MNCs), have received a considerable attention in the academic literature in the last several decades (McCann - Mudambi 2004; Jain et al. 2016). MNCs can be conceptualized as an international network of different units dispersed across several countries and regions, each unit being able to contribute with specific location advantages to the competitiveness of the whole company (Dunning 1988; Colovic - Mayrhofer 2011). Why MNCs choose one location over another still represents an important question, both from an academic and a practical perspective (Nielsen et al. 2017).

For the actors of the global automotive industry, location decisions play a particularly important role in their long-term competitiveness. Since the mid-1980's automotive companies have shifted from a powerful national focus towards a more intensive global presence in terms of carrying out their production processes, thereby introducing location decisions into their strategic agendas. Nowadays, the industry can be characterized as regionally integrated, but globally dispersed, where each continent has its own regional parts production network that supplies final assembly plants to serve the regional markets (Sturgeon et al. 2008). Thus, the industry is currently organized in regional, rather than fully global value chains, meaning that location choices are mainly focused within each region/continent. Globally, the automotive industry is dominated by a moderate number of powerful MNCs, and their competitive position depends, to a large extent, on the geographical configuration of their global production networks 
and, within this, on the location choices made on the level of different regions (Colovic - Mayrhofer 2011).

As regional integration plays an important role in the design of carmakers' global value chains, this paper narrows down its focus on one such region, namely the European automotive industry. Our choice of the European region is also backed up by several recent strategic location decisions made by the major automotive MNCs present in the European market. In 2018 alone, several new locations have been chosen in Europe by these manufacturers: Land Rover established a production plant in Slovakia (JLR 2018a), BMW announced the investments for a new assembly plant in Hungary (BMW 2018), Magna, a seat supplier of BMW, Volkswagen and many others, opened a seat production unit in Czechia (Magna 2018), while Land Rover opened a technical engineering office in the capital of Hungary (JLR 2018b).

In this paper, we use data on the regions of the EU to investigate the relationship between regional competitiveness and the actual location of car manufacturing companies. Therefore, in Section 2 we review the literature on location decisions in general, and in the automotive industry in particular, followed by a discussion of regional competitiveness factors in the EU. Section 3 presents our research methodology, followed by the detailed description of our analyses. Section 4 draws the conclusions of our study, highlighting its implications for theory and practice, limitations and further research tasks.

\section{LITERATURE REVIEW}

\subsection{Location choices of MNCs}

The question of why companies internationalize, i.e. why do MNCs invest in foreign locations and how they choose these locations represents a fundamental issue of several literature streams from economics and business management. Several theoretical models have been developed in the literature to explain foreign direct investments (FDI) undertaken by these companies, and, implicitly, the location decisions connected to these investments (McCann - Mudambi 2004; Faeth 2009). International business literature offers a particularly useful framework, namely the eclectic OLI paradigm developed by Dunning (2001), to explain the internationalization of companies. According to this framework, ownership (O), location (L) and internalization (I) advantages determine the internationalization of production undertaken by MNCs. Ownership advantages refers to a firm's privileged access to specific income-generating assets and to the ability to coordinate these assets internationally that offers an advantage relative to their competi- 
tors. Location advantages include the specific characteristics of the geographical locations where the firm is present that offer favourable conditions for performing certain value creating activities. Finally, internalization advantages refer to the attractiveness of conducting these activities internally within the firm rather than outsourcing them to other firms in foreign locations.

Out of the three OLI elements, the second component is meant to offer explanations to the question: how MNCs decide where to locate their activities internationally (Nielsen et al. 2017). In a literature review on location decisions encompassing several scientific domains, Nielsen et al. (2017) argue that the characteristics of the location of MNCs that are taken into consideration by these firms can be grouped into four major categories. First, and most frequently, economic factors, such as the market size, tax rates, wages, infrastructural development and characteristics of the human capital, are included in several location studies (e.g. Bilbao-Ubillos - Camino-Beldarrain 2008; Jacobs 2017; Pavlínek 2019). Second, the institutional perspective has also been widely considered in the location literature, focusing mainly on the development of formal institutions and on the existence of special economic zones (e.g. Daude - Stein 2007; Jacobs 2017; Pavlínek 2019). Third, factors related to the concentration of firms into industrial clusters have also been proved to be important (e.g. Bhat et al. 2014; Klier - McMillen 2015). Lastly, some of the studies focus on a more fine-grained level of location choices, namely those related to global cities which offer favourable cosmopolitan environments for MNC operations (e.g. He 2003; Goerzen et al. 2013). Furthermore, the level of analysis is also diverse in the location literature. Some papers take a country-level perspective (e.g. Colovic - Mayrhofer 2011; Jacobs 2017), others investigate location decision on a sub-national regional level (e.g. Cieslik 2005; Klier - McMillen 2015), while other papers study the issue on the level of cities or industrial clusters (e.g. He 2003; Jofre-Monsey et al. 2014; Guzman 2015). Given the diversity of this field, several comprehensive studies have been published in the last couple of years that offer an extensive overview of the field of location decisions (Arauzo-Carod et al. 2010; Kim - Aguilera 2015; Jain et al. 2016; Nielsen et al. 2017).

The aim of our paper is not to review the multitude of the location decision factors included in previous empirical studies: here we take a regional perspective and investigate the extent to which different regional competitiveness factors can be associated with the location of automotive units. Out of the four categories mentioned by Nielsen et al. (2017), we will focus on the first two categories, namely economic and the institutional factors, as these are the ones that can be assessed on, and characterize most accurately, the regional level. 


\subsection{Location decisions in the automotive industry}

As argued in the introduction, the global automotive industry represents a specific case in terms of location patterns: most automotive value chains are present with final assembly plants on each major continent (such as Europe or North America) or large country (such as China or India) together with their own regionally integrated supplier network (Rugman - Collinson 2004; Sturgeon et al. 2008). Within these macro-regions there is a general shift towards more low-cost regions (Pavlínek 2019) without, however, being clear which regional competitiveness factors play a determining role for automotive MNCs to select the exact destination region (Sturgeon et al. 2008).

The shift from national towards regional production value chains has started in the European automotive industry in the early 1990's (Pavlínek 2015). Prior to this period the forefront of this industry, especially in terms of technology and innovation, was represented by the Western European countries, while in the socialist markets of Central and Eastern Europe (CEE) domestic manufacturers enjoyed a virtual monopoly in producing cars with lower productivity and with comparatively lower quality due to weak competitive pressures. Cooperation between the two European regions started to show signs of revival starting in the 1980 's, while the fall of communist regimes peremptorily enabled the integration of the two production networks starting from the 1990's (Pavlínek 2002). During the 2000's, together with the admission of several CEE countries to the $\mathrm{EU}$, this integration process has been intensified, with the CEE countries becoming increasingly dependent on this industry (Bilbao-Ubillos - Camino-Beldarrain 2008; Túry 2014; Pavlínek 2015; Ambroziak 2018). Beside the construction of new production sites, a considerable upgrading has also taken place, the CEE plants moving towards performing higher value-added activities, including research and development (Jürgens - Krzywdzinski 2009). Nevertheless, it has to be also noted that while this upgrading is certainly present, it is still limited in the CEE region (Sass - Szalavetz 2009; Demeter - Szász 2016). Nowadays, many large investments continue to target the CEE region, a tendency that will possibly continue with the expected rise of e-car manufacturing as well.

Given the particularities of the global and European automotive industry, several papers focus explicitly on the location decisions of automotive MNCs. Colovic - Mayrhofer (2011), for example, show that while most car manufacturers used to prefer to locate production and $\mathrm{R} \& \mathrm{D}$ activities in their home countries, the search for more attractive geographic locations has accelerated recently, FDI being the most significant in terms of establishing new production plants, and to some extent new R\&D units abroad. Analogously, Pavlínek (2019) shows that 
several automotive companies have invested heavily in the CEE regions mainly to benefit from the significantly lower labour costs.

Based on these developments, we have conducted a systematic search of the academic literature focusing on journal articles published after 1990 that investigate location decisions exclusively in the automotive sector, using the combinations of the following search terms: "location", "localization", "location factor", "automotive industry" and "car industry". A centralized search engine has been used that offers simultaneous access to multiple scientific databases (Academic Search Premier, DOAJ, Sage, ScienceDirect, SpringerLink, Taylor \& Francis Online, Wiley Online Library) containing 15,000+ academic journals. In addition, we used the snowballing technique by analysing the list of references of selected articles (including review-type papers) to identify additional relevant studies. These studies are summarized in Table 1.

Based on our literature search, it is surprising that the number of scientific articles that investigate location decisions exclusively in the automotive sector represents a rather small section of the volume of the general literature on location decisions. Furthermore, studies that use statistic or econometric methods to generalize automotive location decisions are even scarcer. Therefore, we believe that there is a need for a comprehensive analysis of location factors in the automotive sector, especially in the lights of the recent developments in the European (and also in the global) automotive market. The significance of the European market is also backed up by the majority of publications included in Table 1 that focus on some part of the European automotive industry. However, none of these papers investigate from a regional perspective of the factors of regional competitiveness that can be associated with the location of car manufacturing companies in the EU, although such a study could offer important input for regional policy makers by pointing out those regional features that need to be developed in order to attract automotive MNCs.

Such an analysis would be especially relevant for Europe, where several countries, especially the CEE countries, are heavily dependent on this manufacturing sector (Bilbao-Ubillos - Camino-Beldarrain 2008; Pavlínek 2015, 2019). Therefore, in the next subsection we review the factors of regional competitiveness and assess the extent to which these can represent location decision factors for MNCs.

\subsection{Components of regional competitiveness as location factors}

There is a unique project in the EU that aims to assess the competitiveness of regions, computing a composite indicator for each region of the EU, i.e. the Regional Competitiveness Index (RCI). Published first in 2010, the RCI represents 


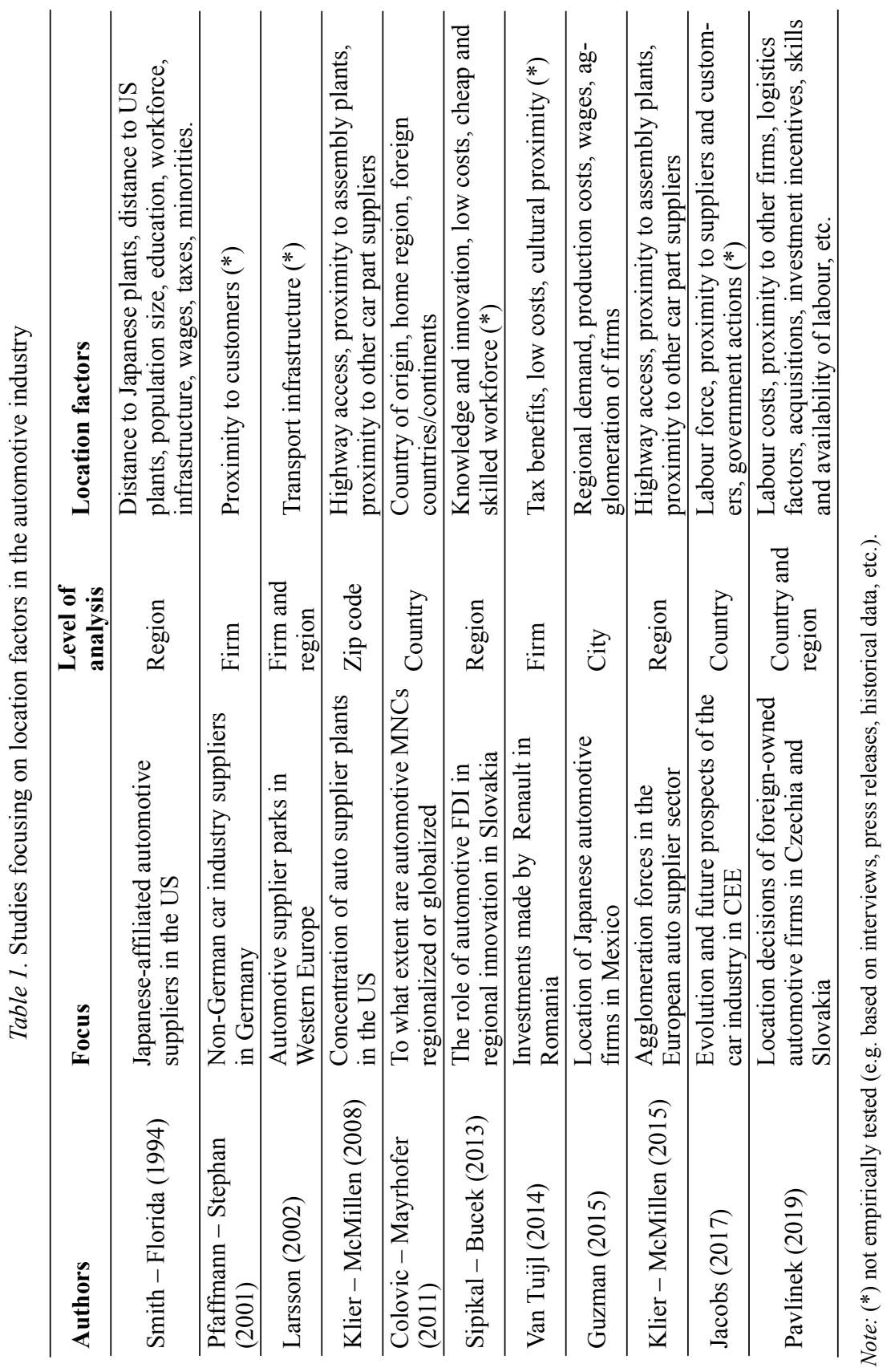


the first ever indicator to measure the competitiveness of the EU regions (Dijkstra et al. 2011). Regions are defined on the NUTS2 (Nomenclature of Territorial Units for Statistics) level, which is based on a common statistical classification of territorial units enabling a uniform collection and compilation of statistical data in the EU. The RCI is based on the most widely used global competitiveness index, published on a yearly basis by the World Economic Forum in its Global Competitiveness Report series (Schwab 2018). The RCI report defines regional competitiveness as "the ability (of every region) to offer an attractive and sustainable environment for firms and residents to live and work" (Dijkstra et al. 2011: 4). In this sense, the RCI represents an appropriate proxy for measuring the attractiveness of regions for car manufacturing companies. Table 2 summarizes our set of indicators, including their explanation, level of measurement and their support by previous literature as possible location factors. The utilization of these indicators as location factors is also backed up by the study of Ramirez-Alesón Fleta-Asín (2016), who use the components of the Global Competitiveness Index (Schwab 2018) to analyse country-level location factors. Here, a similar approach is employed, but instead of country-level we investigate the issue on regional level.

Starting from the approach employed by Ramirez-Alesón - Fleta-Asín (2016), we restricted further the scope of selected location factors based on two criteria. In order to be used in our analysis, each factor presented in Table 2 had to (1) clearly represent a regional-level indicator, i.e. be different across different regions in the same country, and had to (2) be supported by previous literature on the location choices of MNCs. Thus, macroeconomic stability and basic education were eliminated for being pure country-level indicators. We further excluded the health pillar for not having a substantial support in previous literature. Lastly, market size was also filtered out from our study. Although market size has some support in previous studies, it generally refers to the country-level (e.g. Disdier Mayer 2004) or macro-regions (Cheng - Kwan 2000). Furthermore, market size in the European automotive sector is less relevant due to the shorter distances between countries and regions and to the easiness of undertaking exporting activities (Cheng - Kwan 2000). Thus, the final list of location factors consists of the following regional competitiveness factors: institutions, infrastructure, higher education and lifelong learning, labour market efficiency, technological readiness, business sophistication and innovation. 


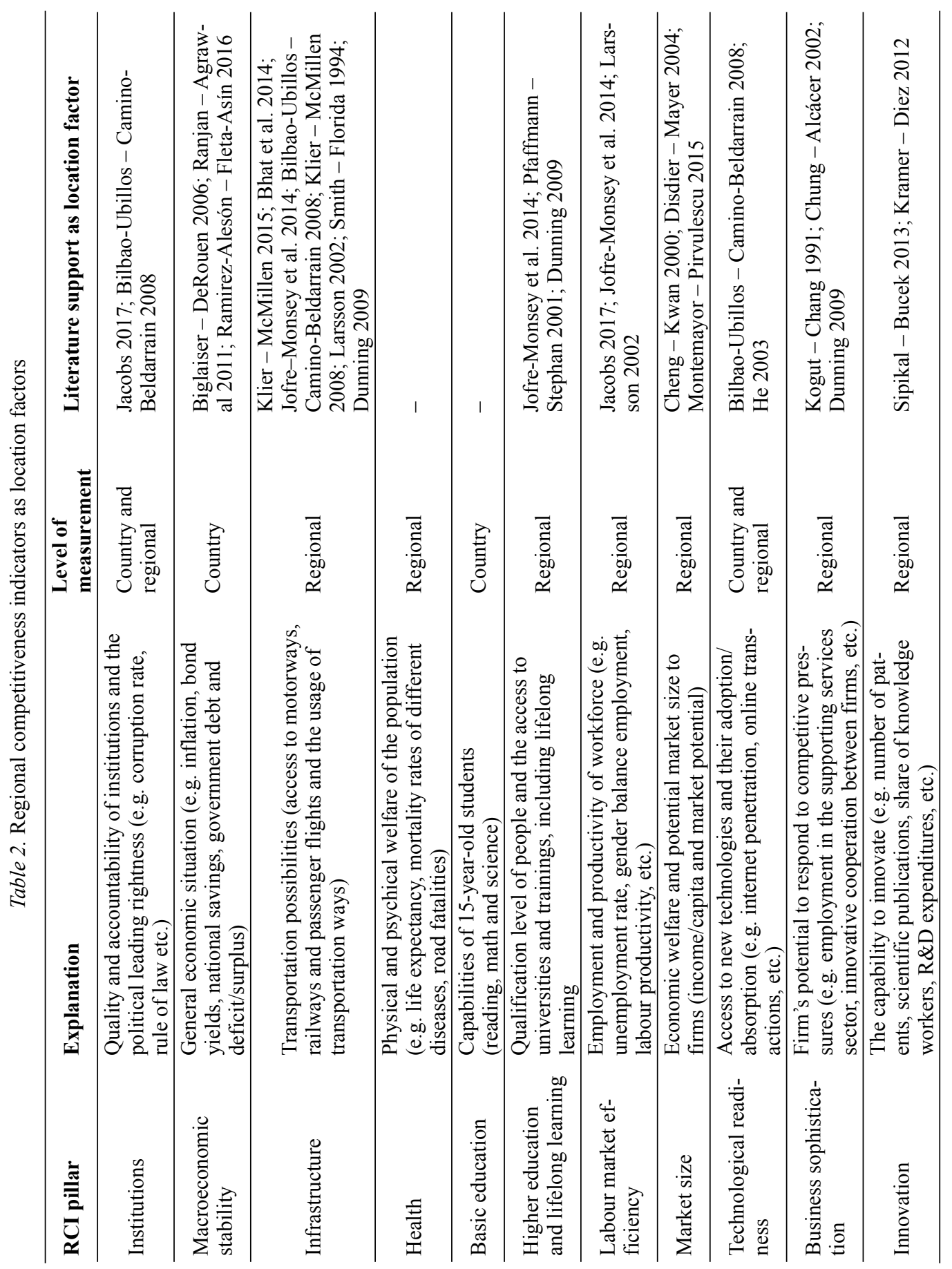




\section{RESEARCH METHODOLOGY}

To investigate the role of regional competitiveness factors in the location of car manufacturing $\mathrm{MNC}$ units, we combined regional competitiveness data with plant-level location data. To assess regional competitiveness, we use the latest edition of the EU RCI 2016 published by the European Commission (Annoni et al. 2017). The index contains detailed regional competitiveness data on altogether 276 NUTS2 regions within the EU, being composed of 74 regional indicators which are combined into 11 pillars as presented in the previous section. Out of these 11 pillars, we use 7 factors, which are clearly regional indicators and have been supported by previous literature on MNC location. All factors are measured as standardized values and are introduced in the regression models as independent variables.

Next, plant-level location data was collected for which we used a rigorous 4-step method described in Figure 1.

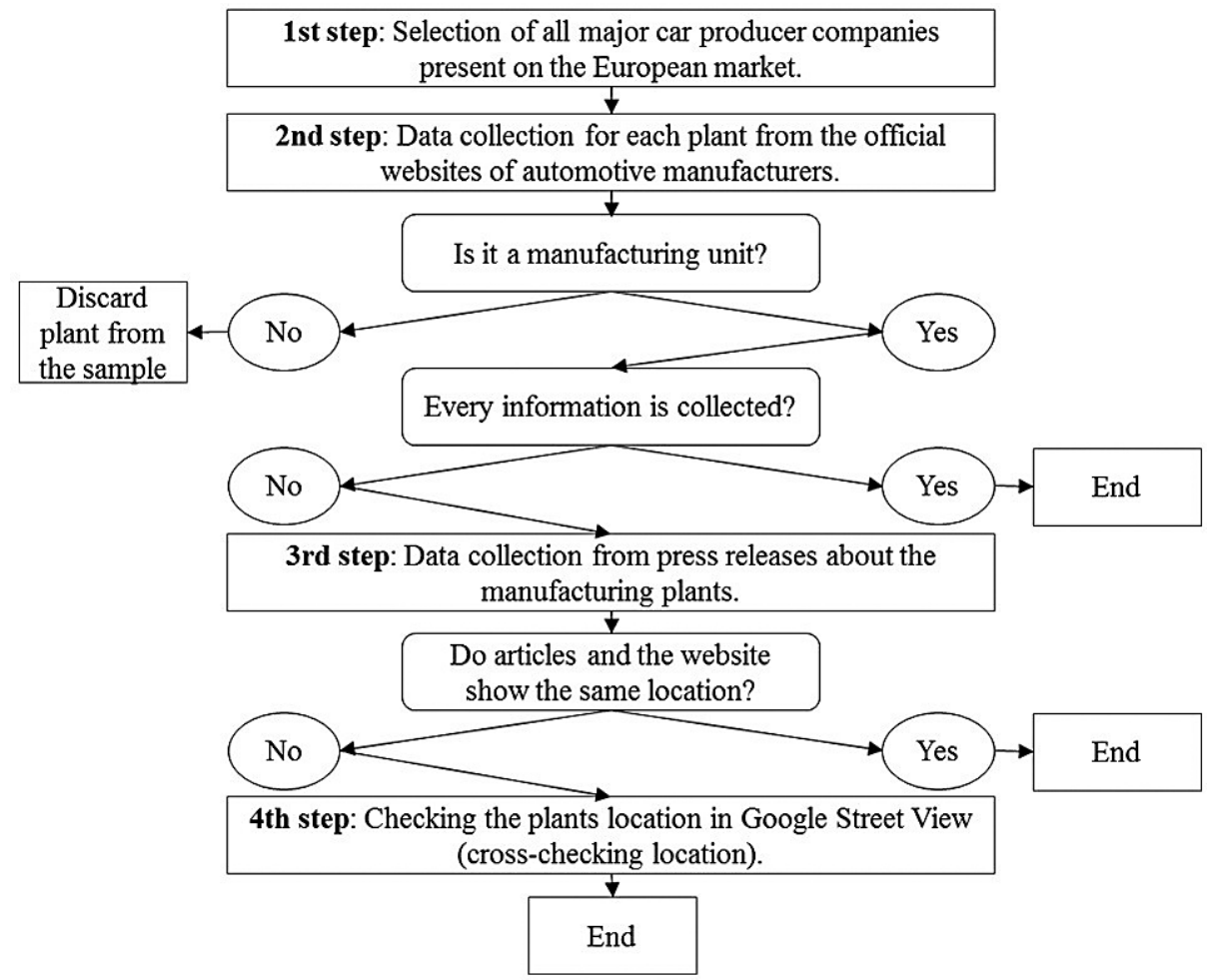

Figure 1. A 4-step methodology was used to define the sample of automotive units in the EU 
First, we listed all major car manufacturing companies $\left(\mathrm{OEMs}^{1}\right)$ that are present in the EU market. In the second step, we collected data for each unit operating within the internal network of the company using the official websites of these companies. These data referred to the exact location of each plant (country, region, and city), the year of foundation of the plant, the current number of employees and the type of processes operated by the plant (component manufacturing, final assembly, R\&D). Here, we restricted our sample to units that carry out some types of production activity. Thus, distribution centres, logistic units, sales units and R\&D centres have been filtered out from our sample, reaching thereby a homogeneous sample in terms of location behaviour. Further, year of foundation and the number of employees have been used as proxies to determine whether the plant is still operational given its age and current level of employment. If we were unable to collect all the information listed above about a plant, we searched for official press releases (e.g. on plant opening or employee numbers) to complete the information. Further, if there was a discrepancy in respect of plant location between the official website of the company and press releases, we have used Google's Street View service to validate actual location. After this process, we have arrived at a sample of 269 automotive plants located in the EU belonging to 20 different car manufacturing companies. The composition of our sample of automotive units in respect of country of location and company group is presented in Tables 3 and 4.

To support the reliability and representativeness of the sample, and to demonstrate that no important units have been overlooked, we examined the share of the automotive companies included in our sample in the global car market. The 20 companies included in our sample represent $79.6 \%$ of the total worldwide automotive market in 2016, the remaining $21.4 \%$ of car makers being composed of mainly Chinese manufacturers who are not currently present in the European market (OICA 2016). Based on this list, we can be fairly confident that no important automotive locations are missing from our sample. These locations, together with the companies they belong to, are illustrated in Figure 2.

To combine regional and plant location data, we have assigned to each NUTS2 region a binary value, where 1 represents that the region has at least one automotive unit within its territory, while 0 represents that the region has currently no

In our automotive sample original equipment manufacturer (OEM) refers to a car assembly company. OEMs in most of the cases produce only the body and the engine of the cars and some elements from the powertrain (e.g. the differential, the axles, the gearshift system). Many other car parts are bought from a Tier 1 supplier, a company whose goods are directly used as inputs by car manufacturers. Our sample includes only OEM plants. The main activity of these plants is car assembly and/or body parts manufacturing and/or engine manufacturing and/or the production of powertrain elements. 
Table 3. Composition of the sample of automotive units in the EU by countries

\begin{tabular}{lcc|lcc}
\hline Country & $\begin{array}{c}\text { Frequency } \\
\text { (pcs.) }\end{array}$ & $\begin{array}{c}\text { Relative } \\
\text { frequency (\%) }\end{array}$ & Country & $\begin{array}{c}\text { Frequency } \\
\text { (pcs.) }\end{array}$ & $\begin{array}{c}\text { Relative } \\
\text { frequency (\%) }\end{array}$ \\
\hline Austria & 8 & 3.0 & Netherlands & 2 & 0.7 \\
Belgium & 2 & 0.7 & Poland & 16 & 5.9 \\
Czechia & 9 & 3.3 & Portugal & 6 & 2.2 \\
Denmark & 2 & 0.7 & Romania & 5 & 1.9 \\
Finland & 1 & 0.4 & Slovakia & 6 & 2.2 \\
France & 46 & 17.1 & Slovenia & 3 & 1.1 \\
Germany & 65 & 24.2 & Spain & 21 & 7.8 \\
Hungary & 4 & 1.5 & Sweden & 15 & 5.6 \\
Italy & 33 & UK & 25 & 9.3 \\
\hline \multicolumn{5}{r}{ Total } \\
\hline
\end{tabular}

Table 4. Composition of the sample of automotive units in the EU by companies

\begin{tabular}{|c|c|c|c|}
\hline OEM & Brand & Frequency (pcs.) & $\begin{array}{c}\text { Relative } \\
\text { frequency } \\
(\%)\end{array}$ \\
\hline Aston Martin & Aston Martin & 3 & 1.1 \\
\hline BMW Group & BMW, Mini, Rolls-Royce & 13 & 4.8 \\
\hline Chaterman Car & Chaterman & 1 & 0.4 \\
\hline Daimler-Benz & $\begin{array}{l}\text { Mercedes-Benz, Smart, } \\
\text { Mercedes-Benz Truck and Bus }\end{array}$ & 35 & 13.0 \\
\hline $\begin{array}{l}\text { FCA (Fiat-Chrysler } \\
\text { Automobiles) }\end{array}$ & $\begin{array}{l}\text { Fiat, Alfa Romeo, Jeep, Lancia, } \\
\text { Maserati, Ferrari }\end{array}$ & 46 & 17.1 \\
\hline Ford Motor Company & Ford & 7 & 2.6 \\
\hline General Motors & Opel* & 11 & 4.1 \\
\hline Honda Motor Company & Honda & 5 & 1.9 \\
\hline Hyundai Motor Group & Hyundai, Kia & 2 & 0.7 \\
\hline Lotus (Geely) & Lotus & 1 & 0.4 \\
\hline McLaren Automotive & McLaren & 1 & 0.4 \\
\hline Morgan Motor & Morgan & 1 & 0.4 \\
\hline Nissan Motor Company & Nissan & 4 & 1.5 \\
\hline PSA Group & Peugeot, Citroën, DS & 28 & 8.9 \\
\hline Renault Group & Renault, Dacia & 18 & 6.7 \\
\hline Suzuki Motor Corporation & Suzuki & 1 & 0.4 \\
\hline Tata Motors & Land-Rover, Jaguar & 5 & 1.9 \\
\hline Toyota Motor Corporation & Toyota & 7 & 2.6 \\
\hline Volvo Group (Geely) & Volvo, Volvo Truck & 22 & 8.2 \\
\hline VW Group & $\begin{array}{l}\text { Seat, Škoda, Volkswagen, Audi, } \\
\text { Porsche, Lamborghini, Bugatti, } \\
\text { Scania, MAN, Ducati }\end{array}$ & 62 & 23.0 \\
\hline Total & & 269 & 100.0 \\
\hline
\end{tabular}

Note: * Since 2017 it is owned by the PSA Group. 


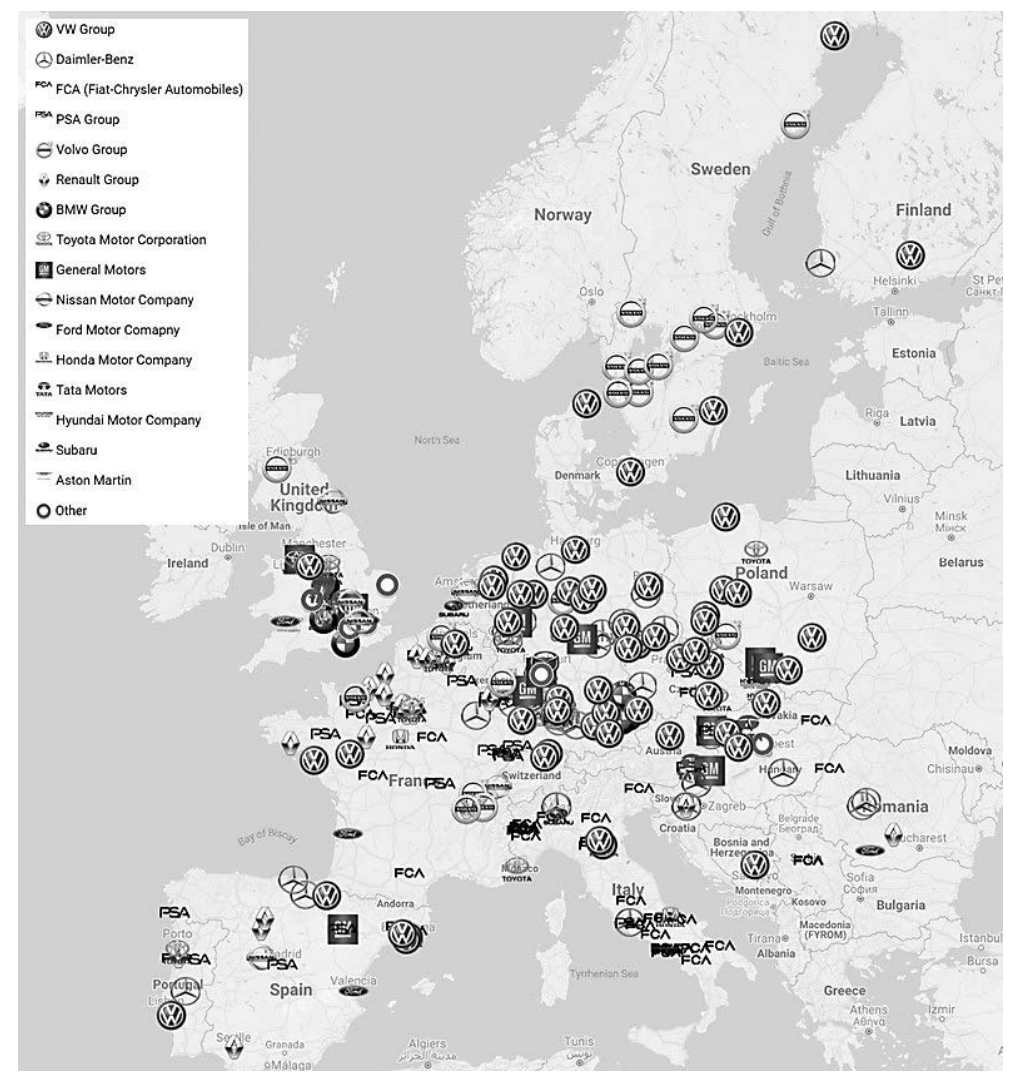

Figure 2. Map of current locations of car manufacturing companies in the EU

Source: Own editing based on Google Maps.

such units within its territory. The decision of creating a binary categorical variable is based on the assumption that if a region contains at least one automotive unit, it means that it has been rated as a suitable location by at least one car manufacturing company compared to several alternative regions. This study seeks to understand the specific characteristics of these regions compared to regions that have not yet attracted car manufacturers. This objective is coherent with the territory-based approach used in the literature which holds that "it is within a given geographical space that agents meet their requirements and satisfy their interests, thanks to a specific context that results from a historical, cultural, social and political process [within the region]" (Bilbao-Ubillos 2010: 358). In concordance with this approach, we combine current regional competitiveness with current regional data instead of using the year of establishment of each location which is a meaningful technique, as the vast majority of car manufacturing units were 
established prior to the launch of the RCI report, and maintaining a current location also implies the location decision of not moving a unit to another geographic area (Slack et al. 2016).

\section{DATA ANALYSIS AND RESULTS}

\subsection{Analysis of the complete sample of the $E U$ regions}

Given that our dependent variable is a binary categorical variable, binary logistic regression is applied to use the selected regional location factors to predict the odds that a region was selected as a location by at least one automotive company. In logistic regression, the logit value of the dependent variable (Location) is calculated by computing the logarithm of the odds that a location (region) was selected by at least one automotive company (Hair et al. 2010). Seven regional competitiveness factors, namely institutions (Inst), infrastructure (Infr), higher education and lifelong learning $(\mathrm{HiEd})$, labour market efficiency ( $L a b M k$ ), technological readiness (Tech), business sophistication (BusSoph) and innovation (Innov), are used to predict the logit value of the dependent variable, where the exponentiated $\beta$ coefficients of predictor variables represent the multiplicative impact of each unit change of the regional competitiveness factor on the odds of a region to contain at least one automotive MNC unit. Thus, the model is specified as follows:

$$
\begin{gathered}
\operatorname{Logit}(\text { Location })=\beta_{0}+\beta_{1} \cdot \text { Inst }+\beta_{2} \cdot \operatorname{Infr}+\beta_{3} \cdot \text { HiEd }+ \\
+\beta_{4} \cdot \text { LabMk }+\beta_{5} \cdot \text { Tech }+\beta_{6} \cdot \text { BusSoph }+\beta_{7} \cdot \text { Innov }
\end{gathered}
$$

Results of the model estimation including all 276 EU regions, together with the goodness-of-fit measures of the logistic regression model, are presented in Table 5. Results on the complete EU sample show that two location factors (Infr and Innov) have a positive impact on the odds of the EU regions to host an automotive unit. Exponentiated values of the logistic regression coefficients indicate that a unit increase in the infrastructure score of a region increases the odds of being a target location for car manufacturing companies by 2.358 times. The same multiplicative impact in case of the innovation factor is 2.880 . Several other regional competitiveness factors that were suggested by literature to improve the odds of a region to become a target location for (automotive) companies (HiEd, LabMk, Tech) have no such effect in our case. More surprisingly, however, two other factors (Inst, BusSoph) have a negative impact on the odds of regions to become the target locations. As this latter finding clearly goes against the mainstream 
Table 5. Results of the logistic regression model for all EU regions

\begin{tabular}{|c|c|c|c|c|}
\hline & 及 (S.E.) & Wald statistic & p-value & $\operatorname{Exp}(\beta)$ \\
\hline Inst & $-1.035(.401)$ & 6.665 & .010 & .355 \\
\hline Infr & $.858(.283)$ & 9.167 & .002 & 2.358 \\
\hline HiEd & $.195(.322)$ & .367 & .545 & 1.216 \\
\hline LabMk & $.286(.333)$ & .739 & .390 & 1.331 \\
\hline Technology & $.561(.450)$ & 1.556 & .212 & 1.752 \\
\hline BusSoph & $-1.158(.319)$ & 13.211 & .000 & .314 \\
\hline Innov & 1.058 (.366) & 8.370 & .004 & 2.880 \\
\hline Constant & $.041(.144)$ & .082 & .775 & 1.042 \\
\hline \multicolumn{2}{|c|}{ Chi-square (sig.) } & \multicolumn{3}{|c|}{$44.926(.000)$} \\
\hline \multirow{2}{*}{\multicolumn{2}{|c|}{$\begin{array}{l}-2 \text { Log likelihood } \\
\text { Nagelkerke } \mathrm{R}^{2}\end{array}$}} & \multicolumn{3}{|c|}{329.693} \\
\hline & & \multicolumn{3}{|c|}{.204} \\
\hline \multicolumn{2}{|c|}{ Cox \& Snell R ${ }^{2}$} & \multicolumn{3}{|c|}{.153} \\
\hline
\end{tabular}

Note: Dependent variable: logit of Location; significant results in bold.

assumption in literature, we further analyse the impact of these two factors. The main question of interest is to investigate why automotive companies choose regions with low Inst scores as location for their units. Therefore, using Inst $=0$ as a cut-off value, we have split our sample into two groups of regions with low and high infrastructure scores. Furthermore, we have used the Location value to distinguish between regions that are the target locations and the ones that are not.

Combining the two split criteria (Inst and Location) altogether four clusters were developed: regions that are automotive locations and have low Inst value (cluster A), regions that are automotive locations with high Inst values (cluster B), regions that do not host automotive companies and have low Inst values (cluster C), and lastly regions with no automotive units, but with high Inst values. Having the four clusters developed, we have used analysis of variance (ANOVA) with LSD post-hoc tests to compare the scores of all other regional competitiveness factors. More specifically clusters A and C are compared to see why some regions with low Inst scores are preferred over other similar regions by automotive companies. Similarly, we also compared clusters B and D to see whether some regions with high Inst scores that are the target locations have other advantages as well compared to other high Inst regions that were not chosen as location by automotive companies. Results are summarized in Figure 3.

The results of the post-hoc tests indicate that cluster A has higher regional competitiveness scores relative to cluster $\mathrm{C}$ in respect of almost all the indicators (except for BusSoph). This finding suggests that although an important number of regions with low Inst scores are chosen as target location by automotive companies, these regions are more competitive in respect of the other location factors than the regions with similarly low Inst scores, but with no automotive units. 


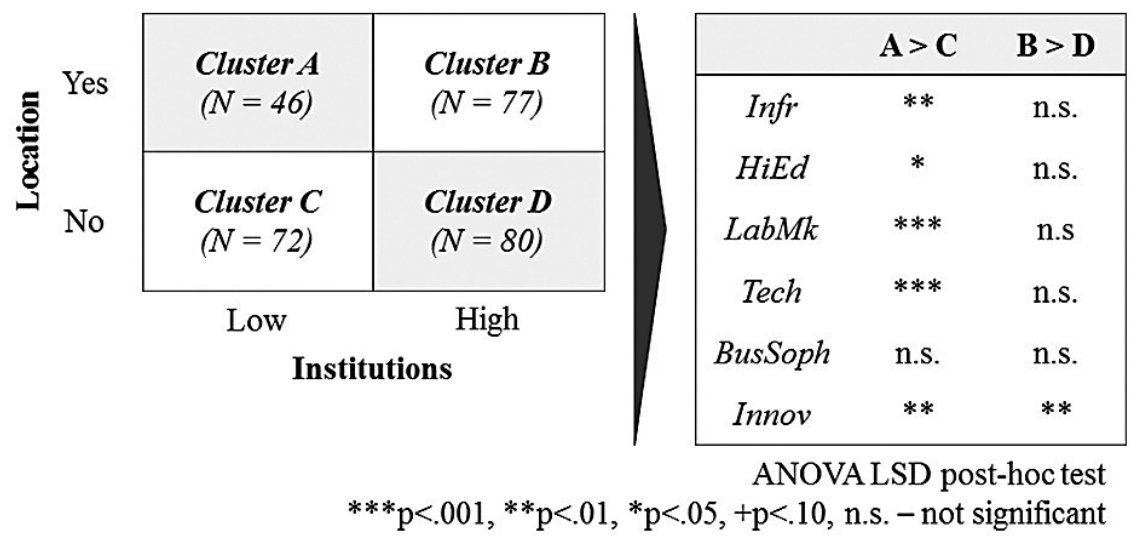

Figure 3. Comparison of location and institution based clusters of the EU regions

Thus, it seems that these factors can compensate for the lack of high institutional development in many regions. Similarly, when comparing two institutionally highly developed clusters (B and D), regions that are target locations (cluster B) are more competitive in respect of Infr and Innov as well. This finding suggests that institutional development alone is not enough for a region to become an automotive location, it has to perform well on the two factors (Infr and Innov) that had a significantly positive impact on location on the whole EU sample as well.

Next, a similar clustering and pairwise comparison has been carried out, using the second regional competitiveness factor with negative impact on location, namely BusSoph. Four clusters have been developed based on the BusSoph score of each region (cut-off value: BusSoph $=0$ ) and on the binary Location variable of

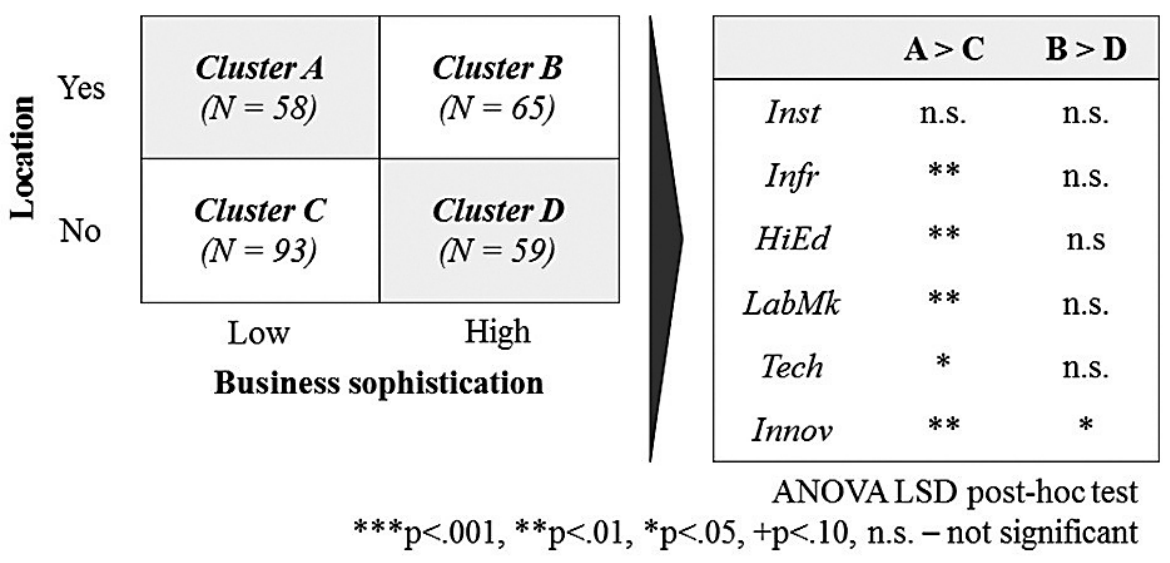

Figure 4. Comparison of location and business sophistication based clusters of the EU regions 
each region. Then, the main clusters of interest have been compared with ANOVA LSD post-hoc tests. Results are summarized in Figure 4.

The tests show similar results as in the case of the Inst factor, and provide some background on the reasons for which BusSoph has a negative impact on Location. While the relationship is negative, regions with low business sophistication score (clusters A and C) are only chosen as location if they show high competitiveness scores on other pillars, except for the Inst factor. Thus, low business sophistication has to be compensated by other location factors for a region to become an automotive location. Similarly, regions with high business sophistication are generally chosen if they outperform other regions with high business sophistication on the Innov score.

\subsection{Analysis of two subsamples of the EU regions}

As most of the recent studies on the European automotive sector emphasize the growing significance of the CEE regions (Túry 2014; Pavlínek 2015; Jacobs 2017; Ambroziak 2018), we have developed two subsamples, the first one containing 56 regions of the CEE regions, the second one being composed of the remaining 220 non-CEE regions belonging mostly to the more developed EU countries of Western and Northern Europe. The breakdown of the two subsamples based on countries and number of regions is presented in Table 6.

Table 6. Two groups of countries: CEE and non-CEE regions

\begin{tabular}{lc|lclr}
\hline \multicolumn{2}{c|}{ CEE countries* } & \multicolumn{4}{c}{ Non-CEE countries } \\
\hline Country & No. of regions & Country & No. of regions & Country & No. of regions \\
\hline Bulgaria & 6 & Austria & 9 & Italy & 21 \\
Czechia & 8 & Belgium & 11 & Luxemburg & 1 \\
Croatia & 2 & Cyprus & 1 & Malta & 1 \\
Estonia & 1 & Denmark & 5 & Netherlands & 12 \\
Hungary & 7 & Finland & 5 & Portugal & 7 \\
Latvia & 1 & France & 27 & Spain & 19 \\
Lithuania & 1 & Germany & 38 & Sweden & 8 \\
Poland & 16 & Greece & 13 & UK & 40 \\
Romania & 8 & Ireland & 2 & & \\
Slovenia & 2 & & \multicolumn{5}{|c}{} \\
Slovakia & 4 & & \multicolumn{5}{|c}{ Total non-CEE } \\
Total CEE & $\mathbf{5 6}$ & \multicolumn{5}{|c}{} \\
\hline
\end{tabular}

Note: * Based on OECD definition. 
Using the two subsamples, we have run the logistic regression model specified in the previous subsection for both non-CEE and CEE regions. Results of the model for the non-CEE regions are detailed in Table 7.

Table 7. Results of the logistic regression model for the non-CEE EU regions

\begin{tabular}{|c|c|c|c|c|}
\hline & $\boldsymbol{\beta}$ (S.E.) & Wald statistic & p-value & $\operatorname{Exp}(\beta)$ \\
\hline Inst & $-2.020(.665)$ & 9.216 & .002 & .133 \\
\hline Infr & $.600(.301)$ & 3.972 & .046 & 1.822 \\
\hline HiEd & $.395(.366)$ & 1.165 & .281 & 1.484 \\
\hline LabMk & $.904(.423)$ & 4.566 & .033 & 2.470 \\
\hline Tech & $.765(.659)$ & 1.346 & .246 & 2.148 \\
\hline BusSoph & $-1.192(.370)$ & 10.402 & .001 & .304 \\
\hline Innov & 1.179 (.399) & 8.707 & .003 & 3.250 \\
\hline Constant & $.313(.185)$ & 2.862 & .091 & 1.368 \\
\hline \multicolumn{2}{|c|}{ Chi-square (sig.) } & \multicolumn{3}{|c|}{$45.227(.000)$} \\
\hline \multicolumn{2}{|c|}{-2 Log likelihood } & \multicolumn{3}{|c|}{252.598} \\
\hline \multicolumn{2}{|c|}{ Nagelkerke $\mathrm{R}^{2}$} & \multicolumn{3}{|c|}{.253} \\
\hline \multicolumn{2}{|c|}{ Cox \& Snell $R^{2}$} & \multicolumn{3}{|c|}{.190} \\
\hline
\end{tabular}

Note: Dependent variable: logit of Location; significant results in bold.

Results of the regression model indicate that in the non-CEE regions several location factors have a positive impact on the odds of a region to become a target location for automotive companies. A more developed infrastructure (Infr), a more efficient labour market $(L a b M k)$ and a more innovative environment (Innov) all contribute to a region's attractiveness for automotive companies. On the other hand, the two unexpected factors with negative impact on the total sample have a similar impact on the non-CEE subsample as well. Therefore, a similar clustering has been carried out as in the case of the total sample to investigate in detail the negative impact of Inst and BusSoph on location. Results are presented in Figures 5 and 6.

Summarizing the results presented in Figures 5 and 6, main conclusions are similar to those identified on the total EU sample. In concordance with the negative impact of the two factors, several regions with low Inst and BusSoph scores are chosen as target locations by car manufacturing companies, but only if they outperform other low Inst and BusSoph regions on most of the other location factors. Thus, low Inst and BusSoph need to be compensated by other regional competitiveness factors (including the ones that had positive impact on location in the regression model) in order for a region to become a target location of car manufacturing companies. On the other hand, regions with high Inst and BusSoph 


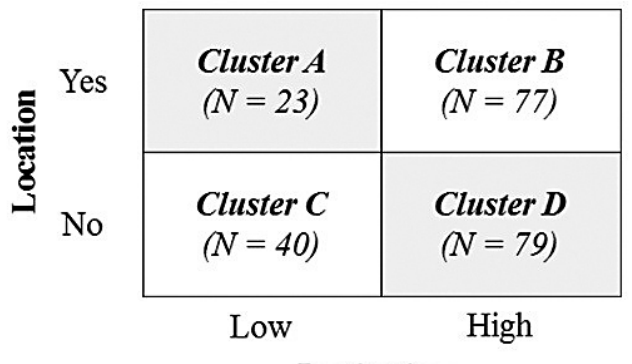

Institutions

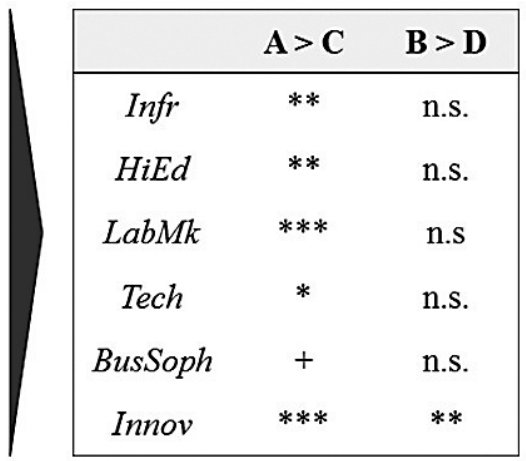

ANOVA LSD post-hoc test ${ }^{* * *} \mathrm{p}<.001,{ }^{* *} \mathrm{p}<.01,{ }^{*} \mathrm{p}<.05,+\mathrm{p}<.10$, n.s. - not significant

Figure 5. Comparison of location and institution based clusters of the non-CEE regions

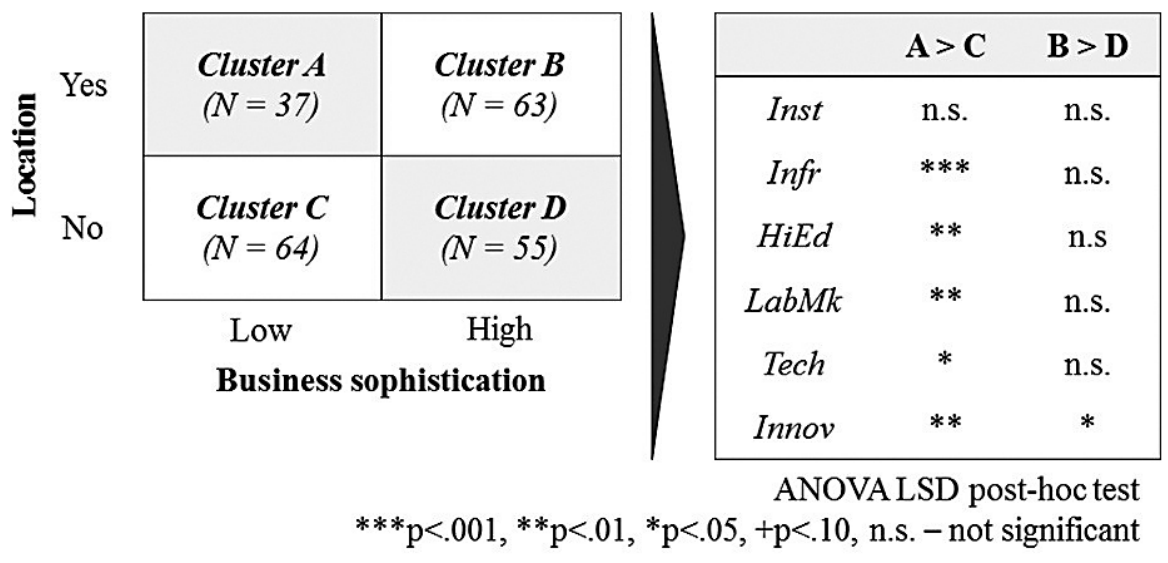

Figure 6. Comparison of location and business sophistication based clusters of the non-CEE regions

are only chosen by these companies if they have higher scores on the Innov factor and to some extent on the Infr factor.

Lastly, the previously introduced binary logistic regression model has been run on the CEE sample as well. Here, we have to note that the size of the CEE sample is rather small, which cannot be artificially increased, and results have to be taken into consideration with caution, even though the fit statistics of the model still yield close to acceptable goodness-of-fit measures. Results are detailed in Table 8. 
Table 8. Results of the logistic regression model for the CEE regions

\begin{tabular}{|c|c|c|c|c|}
\hline & $\beta$ (S.E.) & Wald statistic & p-value & $\operatorname{Exp}(\beta)$ \\
\hline Inst & $-1.631(1.127)$ & 2.094 & .148 & .196 \\
\hline Infr & $3.136(1.672)$ & 3.518 & .061 & 23.004 \\
\hline HiEd & $1.333(1.171)$ & 1.296 & .255 & 3.793 \\
\hline LabMk & $.601(1.494)$ & .162 & .687 & 1.824 \\
\hline Tech & $1.075(.835)$ & 1.658 & .198 & 2.929 \\
\hline BusSoph & $-2.588(1.463)$ & 3.129 & .077 & .075 \\
\hline Innov & $-.331(1.875)$ & .028 & .868 & .732 \\
\hline Constant & $-.332(1.442)$ & .053 & .818 & .717 \\
\hline \multicolumn{2}{|c|}{ Chi-square (sig.) } & \multicolumn{3}{|c|}{$13.787(.055)$} \\
\hline \multicolumn{2}{|c|}{-2 Log likelihood } & \multicolumn{3}{|c|}{62.050} \\
\hline \multicolumn{2}{|c|}{ Nagelkerke $\mathrm{R}^{2}$} & \multicolumn{3}{|c|}{.294} \\
\hline \multicolumn{2}{|c|}{ Cox \& Snell R ${ }^{2}$} & \multicolumn{3}{|c|}{.218} \\
\hline
\end{tabular}

Note: Dependent variable: logit of Location; significant results in bold.

Due to the smaller sample size, significant results on the $p<.10$ level are also taken into consideration (Hair et al. 2010). Results of the regression model show that in the CEE regions Infr has a positive impact on the odds of a region to become a target location, while BusSoph has a negative impact. None of the other factors reaches a significant level of influence on Location. Again, to gain a deeper understanding of the unexpected negative impact of the BusSoph factor, we developed four clusters based on the same procedure as in the previous cases. Results are summarized in Figure 7. Results, however, show a somewhat different pattern than in the case of the non-CEE regions. Cluster A (regions with low business sophistication chosen as location by automotive companies) has only some advantage over cluster $\mathrm{C}$ (regions with low business sophistication not chosen as location by automotive companies) in respect of Infr. Thus, it seems that infrastructural development plays a key role in the CEE regions: not only that it has an overall positive impact on Location, but it can also compensate to a certain extent the low business sophistication of some regions. Comparing clusters B and $\mathrm{D}$, the former one (regions with high business sophistication chosen as location) underperforms the latter one (regions with high business sophistication not chosen as location) on infrastructural development and technological readiness. Thus, the negative impact on BusSoph is also supported by the fact that business sophistication alone is not enough, and a high infrastructural development and technological readiness is also needed for a region to become a target location for automotive companies. 


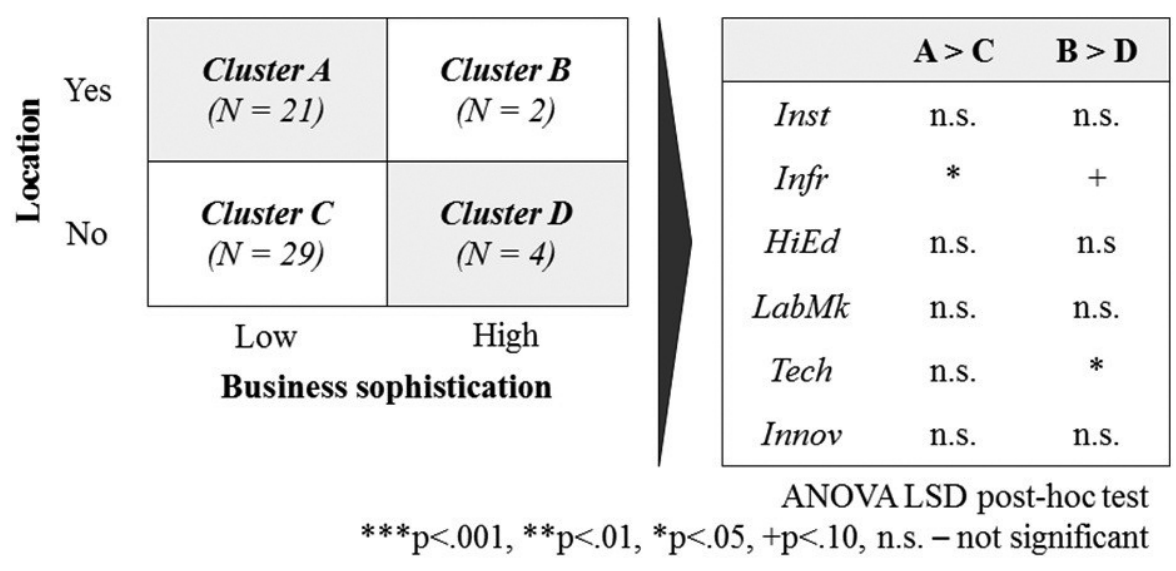

Figure 7. Comparison of location and business sophistication based clusters of the CEE regions

\section{DISCUSSION AND CONCLUSION}

\subsection{Summary and implications}

The purpose of this paper is to contribute to a relatively under-researched area of the location literature by investigating the association between regional competitiveness factors and the location of car manufacturing companies in the EU. An important strength of our approach is that our research sample includes all production and R\&D units operated by car manufacturing companies in the EU. Binary logistic regression analyses are conducted to determine the impact of several regional competitiveness factors on the location choices of these companies, and a more detailed analysis is carried out where our results are contradicting previous findings of the location literature.

First, our findings strongly confirm that infrastructure is one of the most impactful location factors for MNCs (Arauzo-Carod et al. 2010; Nielsen et al. 2017), having a significantly positive effect both in the complete EU sample, and in the CEE and non-CEE subsamples. Previous studies in the automotive sector generally found that access to highways is a powerful location factor in terms of transportation infrastructure (Smith - Florida 1994; Klier - McMillen 2008, 2015; Pavlínek 2019). Our findings confirm, and in the same time extend, these results, showing that beside road infrastructure, railway and air transport infrastructure also play a role in the location choices of car manufacturing companies (cf. Table 2). This extension is actually in line with previous location studies carried out in different economic sectors: Cieslik (2005), for example, also finds that 
beside road infrastructure railways and seaports also play a significant role in the location decision of foreign firms located in the Polish regions.

Second, results of our analysis also brought some evidence that an efficient labour market (in the non-CEE regions) and innovation (both in the complete EU sample and in the non-CEE regions) have a significantly positive impact on location. Previous literature showed that both an efficient labour market offering productive employment possibilities (Jofre-Monseny et al. 2014) and an innovative region that is rich in various knowledge sources (Kramer - Diez 2012; Sipikal - Bucek 2013) can positively influence the location choice of MNCs, and this seems to be valid in the case of the automotive sector of the EU as well. Why these factors have no significant impact on location in the CEE regions remains, however, an unanswered question. Based on our regression model, one explanation could be that the infrastructural development is such a highly significant location factor in these regions that other factors play a relatively less important role, making their impact statistically insignificant.

Third, contrary to previous literature we could not confirm the significant impact of several other location factors, such as the level of higher education and technological readiness. Again, one possible explanation could be that the positive impact of the significant location factors (infrastructure, innovation, labour market efficiency) is to such extent stronger that the positive influence of the other two factors (higher education and lifelong learning and technological readiness) remains statistically insignificant. An alternative explanation is provided in the next paragraph.

Fourth, contrary to our expectations, institutions and business sophistication had a negative impact on the location choice of automotive MNCs in the EU. This finding goes clearly against the mainstream assumptions in the literature. Given, however, that CEE (with its less developed institutions and business sophistication) was an important target location in the past three decades for car manufacturers establishing new units in the EU (Pavlínek 2019), the negative impact of the two pillars is not that surprising. The negative impact of institutions could also be traced back to relatively high bargaining power of automotive OEMs where a less developed or weak institutional system could offer more opportunities to exploit this bargaining power. Nevertheless, we have conducted a more detailed analysis (clustering and ANOVA post-hoc tests) to reveal that while regions with less developed institutions and low business sophistication could be attractive for automotive companies, the same regions still have to perform well on most of the other location factors (especially the ones with significant positive impact) to attract automotive units. These results are summarized in Table 9.

From a practical perspective, our results suggest that car manufacturing companies continue to locate their units in the EU regions with highly developed 
Table 9. Summary of the results

\begin{tabular}{|c|c|c|c|}
\hline & EU-28 & non-CEE countries & CEE countries \\
\hline $\begin{array}{l}\text { Main location factors } \\
\text { (positive impact) }\end{array}$ & $\begin{array}{l}\text { Infrastructure, } \\
\text { Innovation }\end{array}$ & $\begin{array}{l}\text { Infrastructure, Labor } \\
\text { market, Innovation }\end{array}$ & Infrastructure \\
\hline $\begin{array}{l}\text { Negative factors, } \\
\text { i.e. they are not needed, } \\
\text { but only if... }\end{array}$ & $\begin{array}{l}\text { Institutions, } \\
\text { Business sophistica- } \\
\text { tion }\end{array}$ & $\begin{array}{l}\text { Institutions, } \\
\text { Business } \\
\text { sophistication }\end{array}$ & $\begin{array}{l}\text { Business } \\
\text { sophistication }\end{array}$ \\
\hline $\begin{array}{l}\text {...they are counterbal- } \\
\text { anced by other factors }\end{array}$ & $\begin{array}{l}\text { Main location } \\
\text { factors + } \\
\text { Higher education, } \\
\text { Labor market, Tech- } \\
\text { nological readiness }\end{array}$ & $\begin{array}{l}\text { Main location } \\
\text { factors }+ \\
\text { Higher education, } \\
\text { Technological readi- } \\
\text { ness }\end{array}$ & $\begin{array}{l}\text { Main location factor } \\
+ \text { to some extent } \\
\text { Technological } \\
\text { readiness }\end{array}$ \\
\hline
\end{tabular}

infrastructures, and to a certain extent with high innovation capabilities and efficient labour markets. To remain competitive, car manufacturing companies should seek to establish new locations primarily in regions with these three attributes. Nevertheless, as our detailed analysis suggests, on a secondary level higher education and lifelong learning and technological readiness should not be neglected either. From a policy perspective, regions that intend to attract automotive FDI should improve primarily the infrastructural development of the region, especially in the CEE region, followed by enhancing local innovation capabilities and improving the efficiency of the labour market.

\subsection{Limitations and further research}

Our study has several limitations that need to be taken into consideration when discussing our results.

The first set of limitations stems from the nature of the data. Our analysis included only those location factors that were included in "The EU Regional Competitiveness Index 2016 Report" and had been reported by previous studies as significant location decision factors. This means that several other location factors, such as labour costs or proximity to other units (Arauzo - Carod et al. 2010; Pavlínek 2019), are not considered in our study that might still have an important impact on the location decisions of car manufacturing companies. Nevertheless, it was not the purpose of this paper to discover the whole set of location decision factors; instead, we have focused solely on the relationship between regional competitiveness and location of car manufacturing companies and used the factors included in the RCI report, which offers a consistent set of location factors with similar data types, structure and collection method for each EU region. 
Naturally, this does not mean that labour cost, for example, is not still one of the primary location decision factors, especially in the European car manufacturing industry. Labour cost has been shown to be the most important location decision factor on the country level for automotive firms (Pavlínek 2019) and, therefore, is an important differentiator between the competitiveness of regions in different countries. Thus, whether an EU region is chosen or not by an automotive firm is not independent from country-level factors, such as labour costs. However, our analysis excluded those competitiveness factors that are primarily determined on a country-level, and has focused instead on a sub-national level to identify those regional-level aspects that need to be developed by EU regions to improve their chances of hosting car manufacturing units.

In addition, we could not take into account different type of investments (e.g. greenfield $v s$ brownfield) or the difference between various types of automotive subsidiaries (i.e. manufacturing $v s \mathrm{R} \& \mathrm{D}$ ) due to the low number of standalone R\&D units in the EU, thus being unable to investigate whether units with different activities require different location advantages (Colovic - Mayrhofer 2011). Furthermore, data on the location of automotive units in the EU refers to the current situation, ignoring the temporal aspect of location decisions. However, as argued by Slack et al. (2016), considering current locations is also a valid approach, as it implies the decision not to move operations from a given location. Future research could investigate, using longitudinal datasets, the way location decisions are modified in time by companies along with the changing characteristics of different target locations or along the different types of activities carried out by automotive units.

Another set of limitations is concerned with the design of this study. As argued before, we have not focused on the dynamics of location decisions. Therefore, we have ignored such important decisions influencing the location of automotive units, as offshoring, backshoring, plant closure or upgrading/downgrading plant operations. How these decisions are influenced by the characteristics of (potential) automotive locations remains an important question for further research.

Finally, our study measured location factors of automotive companies only indirectly, through the characteristics of the regions where these units are located. How location decisions are actually taken and how different regional factors are considered is still underexplored (Pavlínek 2019). Therefore, in the future, preferably case study based research on company-level could further confirm and enrich our findings. 


\section{REFERENCES}

Ambroziak, L. (2018): The CEECs in Global Value Chains: The Role of Germany. Acta Oeconomica, 68(1): 1-29.

Annoni, P. - Dijkstra, L. - Gargano, N. (2017): The EU Regional Competitiveness Index 2016. European Commission Working Paper, No. 02/2017.

Arauzo-Carod, J. M. - Liviano-Solis, D. - Manjón-Antolín, M. (2010): Empirical Studies in Industrial Location: An Assessment of Their Methods and Results. Journal of Regional Science, 50(3): 685-711.

Bhat, C. R. - Paleti, R. - Singh, P. (2014): A Spatial Multivariate Count Model for Firm Location Decisions. Journal of Regional Science, 54(3): 462-502.

Biglaiser, G. - deRouen Jr, K. (2006): Economic Reforms and Inflows of Foreign Direct Investment in Latin America. Latin American Research Review, 41(1): 51-75.

Bilbao-Ubillos, J. (2010): Outlook on Europe: The Spatial Variable in the Recent Configuration of the Value Chain in the European Automotive Industry. Tijdschrift voor Economischeen Sociale Geografie, 101(3): 357-363.

Bilbao-Ubillos, J. - Camino-Beldarrain, V. (2008): Proximity Matters? European Union Enlargement and Relocation of Activities: The Case of the Spanish Automotive Industry. Economic Development Quarterly, 22(2): 149-166.

BMW (2018, July 31): BMW Group to Expand Production Network in Europe. https://www.bmwgroup-werke.com/debrecen/en/aktuelles/new-plant.html, last accessed on: 21.02.2019.

Cheng, L. K. - Kwan, Y. K. (2000): What are the Determinants of the Location of Foreign Direct Investment? The Chinese Experience. Journal of International Economics, 51(2): 379-400.

Chung, W. - Alcácer, J. (2002): Knowledge Seeking and Location Choice of Foreign Direct Investment in the United States. Management Science, 48(12): 1534-1554.

Cieslik, A. (2005): Location of Foreign Firms and National Border Effects: The Case of Poland. Tijdschrift voor Economische en Sociale Geografie, 96(3): 287-297.

Colovic, A. - Mayrhofer, U. (2011): Optimizing the Location of R\&D and Production Activities: Trends in the Automotive Industry. European Planning Studies, 19(8): 1481-1498.

Daude, C. - Stein, E. (2007): The Quality of Institutions and Foreign Direct Investment. Economics \& Politics, 19(3): 317-344.

Demeter, K. - Szász, L. (2016): The Diversity of European Manufacturing Plant Roles in International Manufacturing Networks. Journal of East European Management Studies, 21(2): 184208.

Dijkstra, L. - Annoni, P. - Kozovska, K. (2011): A New Regional Competitiveness Index: Theory, Methods and Findings. European Union Regional Policy Working Paper, No. 02/2011.

Disdier, A. C. - Mayer, T. (2004): How Different is Eastern Europe? Structure and Determinants of Location Choices by French Firms in Eastern and Western Europe. Journal of Comparative Economics, 32(2): 280-296.

Dunning, J. H. (1988): Explaining International Production. London: Unwin Hyman.

Dunning, J. H. (2001): The Eclectic (OLI) Paradigm of International Production: Past, Present and Future. International Journal of the Economics of Business, 8(2): 173-190.

Faeth, I. (2009): Determinants of Foreign Direct Investment - A Tale of Nine Theoretical Models. Journal of Economic Surveys, 23(1): 165-196.

Goerzen, A. - Asmussen, C. G. - Nielsen, B. B. (2013): Global Cities and Multinational Enterprise Location Strategy. Journal of International Business Studies, 44(5): 427-450.

Guzman, L. (2015): Localization Factors from Japanese Firms in Automotive-Related Industries in Mexico. Procedia Economics and Finance, 30: 265-270. 
He, C. (2003): Location of Foreign Manufacturers in China: Agglomeration Economies and Country of Origin Effects. Papers in Regional Science, 82(3): 351-372.

Jacobs, A. J. (2017): Automotive FDI in Emerging Europe: Shifting Locales in the Motor Vehicle Industry. London: Palgrave Macmillan.

Jain, N. K. - Kothari, T. - Kumar, V. (2016): Location Choice Research: Proposing New Agenda. Management International Review, 56(3): 303-324.

JLR (2018a, October 25): Jaguar Land Rover Opens Manufacturing Plant in Slovakia. https:// media.jaguarlandrover.com/news/2018/10/jaguar-land-rover-opens-manufacturing-plant-slovakia, last accessed on: 21.02.2019.

JLR (2018b, November 2): Jaguar Land Rover Confirms Technical Engineering Office in Hungary. https://media.jaguarlandrover.com/news/2018/11/jaguar-land-rover-confirms-technicalengineering-office-hungary, last accessed on: 21.02.2019.

Jofre-Monseny, J. - Marín-López, R. - Viladecans-Marsal, E. (2014): The Determinants of Localization and Urbanization Economies: Evidence from the Location of new Firms in Spain. Journal of Regional Science, 54(2): 313-337.

Jürgens, U. - Krzywdzinski, M. (2009): Changing East-West Division of Labour in the European Automotive Industry. European Urban and Regional Studies, 16(1): 27-42.

Kim, J. U. - Aguilear, R. V. (2016): Foreign Location Choice Review and Extensions. International Journal of Management Reviews, 18(2): 133-159.

Klier, T. - McMillen, D. (2015): Plant Location Patterns in the European Automobile Supplier Industry. Growth and Change, 46(4): 558-573.

Klier, T. - McMillen, D. P. (2008): Evolving Agglomeration in the US Auto Supplier Industry. Journal of Regional Science, 48(1): 245-267.

Kogut, B. - Chang, S. J. (1991): Technological Capabilities and Japanese Foreign Direct Investment in the United States. The Review of Economics and Statistics, 73(3): 401-413.

Kramer, J. P. - Diez, J. R. (2012): Catching the Local Buzz by Embedding? Empirical Insights on the Regional Embeddedness of Multinational Enterprises in Germany and the UK. Regional Studies, 46(10): 1303-1317.

Larsson, A. (2002): The Development and Regional Significance of the Automotive Industry: Supplier Parks in Western Europe. International Journal of Urban and Regional Research, 26(4): 767-784.

Magna (2018, October 11): Magna Wins Additional Seating Business, Celebrates Opening of New Facility. https://www.magna.com/company/newsroom/releases/release/2018/10/11/newsrelease---magna-wins-additional-seating-business-celebrates-opening-of-new-facility, last accessed on: 21.02.2019.

McCann, P. - Mudambi, R. (2004): The Location Behavior of the Multinational Enterprise: Some Analytical Issues. Growth and Change, 35(4): 491-524.

Montemayor, H. M. V. - Pirvulescu, R. (2015): FDI Success Factors: Evidence from a European Manufacturer in the Chinese Automobile Industry. Journal of Management Policy and Practice, 16(2): 61-70.

Nielsen, B. B. - Asmussen, C. G. - Weatherall, C. D. (2017): The Location Choice of Foreign Direct Investments: Empirical Evidence and Methodological Challenges. Journal of World Business, 52(1): 62-82.

OICA: International Organization of Motor Vehicle Manufacturers - Organisation Internationale des Constructeurs d'Automobiles (2016): 2016 Production statistics. http://www.oica.net/ category/production-statistics/2016-statistics/, last accessed on: 28.02.2019. 
Pavlínek, P. (2002): Restructuring the Central and Eastern European Automobile Industry: Legacies, Trends, and Effects of Foreign Direct Investment. Post-Soviet Geography and Economics, 43(1): 41-77.

Pavlínek, P. (2015): The Impact of the 2008-2009 Crisis on the Automotive Industry: Global Trends and Firm-Level Effects in Central Europe. European Urban and Regional Studies, 22(1): 20-40.

Pavlínek, P. (2019): Restructuring and Internationalization of the European Automotive Industry. Journal of Economic Geography, 1-33.

Pfaffmann, E. - Stephan, M. (2001): How Germany Wins out in the Battle for Foreign Direct Investment: Strategies of Multinational Suppliers in the Car Industry. Long Range Planning, 34(3): 335-355.

Ramírez-Alesón, M. - Fleta-Asín, J. (2016): Is the Importance of Location Factors Different Depending on the Degree of Development of the Country? Journal of International Management, 22(1): 29-43.

Ranjan, V. - Agrawal, G. (2011): FDI Inflow Determinants in BRIC Countries: A Panel Data Analysis. International Business Research, 4(4): 255.

Rugman, A. M. - Collinson, S. (2004): The Regional Nature of the World's Automotive Sector. European Management Journal, 22(5): 471-482.

Sass, M. - Szalavetz, A. (2009): Crisis and Upgrading: The Case of the Hungarian Automotive and Electronics Sectors. Europe-Asia Studies, 65(3): 489-507.

Schwab, K. (ed.) (2018). The Global Competitiveness Report 2018. Geneva: World Economic Forum.

Šipikal, M. - Buček, M. (2013): The Role of FDIs in Regional Innovation: Evidence from the Automotive Industry in Western Slovakia. Regional Science Policy \& Practice, 5(4): 475-490.

Slack, S. B. - Jones, A. - Johnston, R. (2016): Operations Management. Edinburgh Gate: Pearson Education Limited.

Smith, D. - Florida, R. (1994): Agglomeration and Industrial Location: An Econometric Analysis of Japanese-Affiliated Manufacturing Establishments in Automotive-Related Industries. Journal of Urban Economics, 36(1): 23-41.

Sturgeon, T. - Van Biesebroeck, J. - Gereffi, G. (2008): Value Chains, Networks and Clusters: Reframing the Global Automotive Industry. Journal of Economic Geography, 8(3): pp. 297-321.

Túry, G. (2014): Automotive Industry in the EU10 Economies: Developments in the Past Decade. In: Éltetö, A. (ed.): Mind the Gap - Integration Experiences of the Ten Central and Eastern European Countries. Budapest: Center for Economic and Regional Studies of the Hungarian Academy of Sciences, Institute of World Economics, pp. 41-60.

Van Tuijl, E. (2014): Car Makers and Upgrading: Renault in Romania. Journal of Business Strategy, 35(2): 13-18. 